\title{
Metabolic Disorders Induced by Fructose- drinking Water Affect Angiotensin II-mediated Intestinal Contractility in Male Wistar Rats
}

Tsvetelin K. Georgiev ${ }^{1}$, Anna N. Tolekova ${ }^{1}$, Nikolay V. Genov ${ }^{2}$, Lilia Zh. Pashova-Stoyanova ${ }^{1}$, Zhivka I. Tsokeva ${ }^{1}$, Krasimira G. Nancheva ${ }^{3}$, Rositsa V. Sandeva ${ }^{1}$, Galina S. Ilieva ${ }^{1}$, Maria G. Ganeva ${ }^{1}$, Petya V. Hadzhibozheva ${ }^{1}$

${ }^{1}$ Department of Physiology, Pathophysiology and Pharmacology, Medical Faculty, Trakia University, Stara Zagora, Bulgaria

${ }^{2}$ Medical student at the Faculty of Medicine, Trakia University, Stara Zagora, Bulgaria

${ }^{3}$ Department of Internal Medicine and Clinical Laboratory, Prof. Dr. Stoyan Kirkovitch University Hospital, Stara Zagora, Bulgaria

Corresponding author: Petya Hadzhibozheva, Department of Physiology, Pathophysiology and Pharmacology, Medical Faculty, Trakia University, Stara Zagora, Bulgaria; E-mail: petia_hadjibojeva@abv.bg; Tel.: +359 886919744

Received: 23 Jan 2020 Accepted: 27 Apr 2020 Published: 31 Dec 2020

Citation: Georgiev TK, Tolekova AN, Genov NV, Pashova-Stoyanova LZ, Tsokeva ZI, Nancheva KG, Sandeva RV, Ilieva GS, Ganeva MG, Hadzhibozheva PV. Metabolic disorders induced by fructose-drinking water affect angiotensin II-mediated intestinal contractility in male Wistar rats. Folia Med (Plovdiv) 2020;62(4):802-11. doi: 10.3897/folmed.62.e50410.

\section{Abstract}

Introduction: The high-fructose diet in rats has been reported to cause metabolic disorders such as impaired fasting glucose levels, insulin resistance, dyslipidemia, and dysregulation of the renin-angiotensin system. This could lead to further complications, for instance, to the smooth muscle dysfunction.

Aim: The present study aimed at developing fructose-induced metabolic perturbations in rats and the investigation of their impact on angiotensin II-induced smooth muscle intestinal motility.

Materials and methods: Mature Wistar rats were randomly divided into two groups ( 9 rats per group): control group (drinking tap water) and fructose-drinking group (15\% fructose, dissolved in tap water). At the end of the experimental period (11 weeks), the plasma levels of insulin, renin, angiotensin II and creatinine, as well as the lipid profile were assessed. Morphometric analysis and lipid index calculation were also performed. The contractile properties of ileum, colon and rectum were studied using stimulation with angiotensin II in the isolated tissue bath system.

Results: Our experiment showed that drinking 15\% fructose solution induced dyslipidaemia accompanied by elevated lipid indexes as well as an increase in creatinine and renin plasma levels in the rats.

Conclusions: Fructose drinking and consequently the developed metabolic disorders modified the Ang II-induced intestinal activity causing a gradual alteration in the distal direction with the rectum being the most strongly affected organ.

\section{Keywords}

angiotensin II, fructose, intestinal dysfunction, metabolic perturbations

Copyright by authors. This is an open access article distributed under the terms of the Creative Commons Attribution License (CC-BY 4.0), which permits unrestricted use, distribution, and reproduction in any medium, provided the original author and source are credited. 


\section{INTRODUCTION}

Many studies reveal the fact that long-term fructose overconsumption produces metabolic alterations leading later to prediabetes and metabolic syndrome (MetS). ${ }^{1,2}$ Prediabetes is a condition that often precedes type 2 diabetes and represents an elevation of plasma glucose levels above the normal values but below that of clinical diabetes. ${ }^{3}$ The MetS is a combination of several clinical symptoms and biochemical changes that in combination increase the risk of developing type 2 diabetes, cardiovascular and other diseases. MetS is diagnosed by the presence of at least three of the following five pathological conditions: abdominal obesity, hypertension, hyperglycaemia, elevated triglycerides and reduced high-density lipoprotein (HDL) cholesterol. ${ }^{4}$ As elevated blood glucose is one of the components of the current definition of both MetS and prediabetes, they can be viewed as closely related to one another. ${ }^{3}$ The persistent hyperglycemia, with or without insulin resistance, causes an excess production of reactive oxygen species (ROS) $)^{5,6}$ and formation of advanced glycation end (AGE) products. ${ }^{2,7}$ Additionally, these factors could contribute to further complications such as the smooth muscle dysfunction. One of the consequences is an impaired gastrointestinal motility, leading to symptoms such as vomiting, abdominal pain, constipation, diarrhoea and faecal incontinence..$^{8-10}$

The high-fructose diet in rats has been used for an induction of MetS or some of its elements as insulin resistance and dyslipidaemia. ${ }^{1,5,6}$ Several studies have established the involvement the overactive renin-angiotensin system (RAS) and the elevated levels of its main effector angiotensin II (Ang II) in insulin resistance and vascular dysfunction in rats on a fructose diet. ${ }^{6,11}$ Furthermore, the RAS blockade has been reported to improve some of the conditions, associated with these metabolic disorders. ${ }^{1,11}$ There is an evidence for a connection between elevated levels of Ang II and the insulin resistance. ${ }^{12}$ Moreover, the increased RAS activity is associated with the impaired lipid metabolism, leading to the development of atherosclerosis. ${ }^{13}$ Comparatively, little is known about RAS influence on gastrointestinal tissues, although Ang II has a proven potent effect on the smooth muscles in the digestive tract. ${ }^{14}$ Despite the observed development of smooth muscle dysfunction and RAS dysregulation in prediabetes and MetS, the net effect of Ang II influence on the intestinal activity in these metabolic disorders is not clear.

\section{AIM}

The aim of this study was to investigate the impact of fructose consumption and the metabolic disorders developed as a consequence on the intestinal response to Ang II stimulation of Wistar rats.

\section{MATERIALS AND METHODS}

\section{Laboratory animals and procedures}

All experiments were carried out according to the guidelines of the Council Directive 2010/63/EU of 22 September 2010 on the protection of animals used for scientific purposes. The animal experiments were approved by the Ethics Committee at the Medical Faculty of Trakia University, Stara Zagora.

Ten-week-old male Wistar rats, weighing around $250 \mathrm{~g}$ were housed in polycarbonate conventional cages $480 \times 375 \times 210 \mathrm{~mm}$ with floor area $1500 \mathrm{~cm}^{2}$ (three animals per cage) in controlled conditions ( $12 \mathrm{~h}$ light/dark cycles), a temperature of $18-23^{\circ} \mathrm{C}$ and humidity of $40 \%-60 \%$. After one-week acclimation period, two groups were formed (9 rats per group): a control group (animals drinking tap water) and experimental fructose-drinking group (animals drinking 15\% fructose dissolved in tap water and injected after 14 days with a single streptozotocin dose of $20 \mathrm{mg} /$ $\mathrm{kg}$ via intra-peritoneal injection). The duration of the experiment was 11 weeks. The design of the experiment was based on Sadeghi et al. ${ }^{15}$ and Wilson and Islam ${ }^{16}$ with some modifications. During the experimental period, body weight (BW), waist circumference (WC) and naso-anal length (NAL) of the animals were monitored weekly. The fasting levels of blood glucose were monitored weekly using a GlucoDr ${ }^{\mathrm{TM}}$ Plus Glucometer (Allmedicus, Anyang, Gyeonggi-do, Republic of Korea). Blood samples were collected from the tail vein in early morning hours.

\section{Experimental protocols}

At the end of the experimental period, the overnight fasted animals were anesthetized with $50 \mathrm{mg} / \mathrm{kg}$ of pentobarbital sodium (Nembutal $\left.{ }^{\circ}\right)$ intraperitoneally and then exsanguinated. Fresh blood (8-10 ml) was collected in EDTA-containers directly from the heart. The blood samples were centrifuged at $4000 \times \mathrm{g}$ at $4^{\circ} \mathrm{C}$ for 10 minutes. The plasma samples were separated and used immediately for assays of: triglycerides (TG), total cholesterol (CHOL), high-density lipoprotein (HDL) cholesterol, low-density lipoprotein (LDL) cholesterol, creatinine, Ang II, renin, and insulin.

The abdominal cavity was opened, and segments from ileum, colon and rectum were dissected out. The ileal segment was taken from $1 \mathrm{~cm}$ proximal to the ileo-cecal valve; the colon segment - from the middle part; the rectum - from the most distal part. Residual contents in the lumen were gently cleared using Krebs solution. The isolated segments were promptly transferred to cold Krebs solution $\left(3^{\circ} \mathrm{C}\right)$ with the following composition (in $\mathrm{mM}$ ): $\mathrm{NaCl}, 118.0, \mathrm{KCl}, 4.74, \mathrm{NaHCO}_{3}, 25.0, \mathrm{MgSO}_{4}, 1.2, \mathrm{CaCl}_{2}$, 2.0, $\mathrm{KH}_{2} \mathrm{PO}_{4}, 1.2$ and glucose, 11.0. The preparation of the intestinal strips and the recording of the mechanical activity were performed as previously described. ${ }^{17}$ In brief, longitudinal strips (approximately $10 \mathrm{~mm}$ long) were dissected 
following the direction of the muscle bundles. Both ends of each strip were tied with ligatures. The distal end was connected to the organ holder; the proximal end was stretched and attached to a mechano-electrical transducer FSG-01 (Experimetria, Ltd., Hungary) via a hook. The preparations were mounted in organ baths TSZ-04/01 (Experimetria, Ltd., Hungary), containing Krebs solution, $\mathrm{pH} 7.4$, continuously infused with Carbogen $\left(95 \% \mathrm{O}_{2}, 5 \% \mathrm{CO}_{2}\right)$. The organ baths were mounted in parallel above an enclosed water bath, thus maintaining the solution temperature at $37^{\circ} \mathrm{C}$ constantly. Strips were placed under an initial tension (preload) of $1 \mathrm{~g}$ and allowed to equilibrate for at least 75 min (three periods: $15 \mathrm{~min}, 45 \mathrm{~min}$, and $15 \mathrm{~min}$ and two washes with Krebs solution between them).

\section{Biochemical laboratory analyses}

TG, CHOL, HDL cholesterol, LDL cholesterol, and creatinine concentration were determined using standard methods on a Mindray BS-300 analyser (Shenzhen Mindray Bio-Medical Electronics Co., Ltd., China). Plasma insulin was measured with a rat enzyme immunoassay kit (Insulin Rat ELISA Wide range Kit, BioVendor, Czech Republic). Ang II and renin plasma levels were determined using Elabscience ELISA Kits (Elabscience Biotechnology Inc., USA) following the manufacturer's protocol. Plasma concentrations of both glucose and insulin were used for the calculation of the insulin resistance index (homeostasis model assessment [HOMA]-IR) according to the formula ${ }^{18,19}$ : fasting insulin $(\mu \mathrm{U} / \mathrm{mL}) \times$ fasting glucose $(\mathrm{mmol} / \mathrm{l}) / 22.5$

\section{Lipid indexes calculation}

To verify the metabolic disturbances, we calculated the following comprehensive lipid indexes ${ }^{20}$ : the $\mathrm{CHOL} /$ HDL ratio, TG/HDL ratio, the lipoprotein combine index $(\mathrm{LCI})=\mathrm{CHOL} \times \mathrm{TG} \times \mathrm{LDL} / \mathrm{HDL}$, and the atherogenic index $(\mathrm{AI})=$ non $\mathrm{HDL} / \mathrm{HDL}$ ratio

\section{Morphometric analysis}

The following morphometric indexes were calculated:

Lee index ${ }^{21}=$ the cubic root of BW (in grams) divided by the NAL $($ in $\mathrm{mm}) \times 104$

Waist-to-stature ratio ${ }^{22}=\mathrm{WC}$ (in $\mathrm{mm}$ ) divided by NAL (in $\mathrm{mm}$ )

\section{Analysis of the Ang II-induced intestinal activity}

After the equilibration period, the intestinal preparations ( $n=9$, per each segment, for each group) were treated with Ang II $(1 \mu \mathrm{mol})$. The mechanical activity was digitized and recorded using ISOSYS-Advanced 1.0 Software (Experimetria, Ltd., Hungary). Data processing and storage for subsequent analysis were performed with the specialized software KORELIA. ${ }^{23,24}$

The duration of the interval for analysis of Ang II-induced intestinal contractions was measured from the beginning of the contraction until the moment at amplitude drop to $50 \%$ of its maximum. This definition was made in order to calculate uniformly the variations in the duration of the contractions. The recorded force versus time graphs allowed the determination of the amplitude and the integral force of the contraction (the latter represented by the area under the curve, AUC). The different phases of Ang II-induced intestinal contractions were analysed by the application of a time-parameter analysis ${ }^{25}$, modified for the study of the smooth muscle contractions. ${ }^{26}$ The following time-parameters were defined: half-contraction time (Thc): the time interval between the beginning of the contraction and half of its maximal force; contraction time (Tc): the time interval between the beginning of the contraction and its maximal force; half-relaxation time (Thr): the interval between reaching the maximal force until the amplitude fell by half; contraction plus half-relaxation time (Tchr): the interval from the beginning of contraction until the moment at which the amplitude drops to $50 \%$ of its maximum.

\section{Chemicals and drugs}

Ang II (Sigma-Aldrich, Germany) was dissolved in bidistilled water. Streptozotocin (Sigma-Aldrich, Germany) was dissolved in cold $0.1 \mathrm{M}$ citrate buffer, $\mathrm{pH}$ 4.5. The fructose solution was prepared by using $150 \mathrm{~g}$ of fructose (Totem DD, Stara Zagora, Bulgaria) dissolved in one litre of drinking water. All reagents for the preparation of Krebs solution were purchased from Sigma-Aldrich, Germany.

\section{Statistical analysis}

The obtained data were analysed using Statistica software v. 8 (Stasoft, Inc., Tulsa, OK) and the results are presented as mean \pm standard error (SE). The obtained values were compared by Student $t$-test. A $p$ value less than or equal to 0.05 was considered to be statistically significant.

\section{RESULTS}

\section{Plasma glucose and insulin levels}

During the experimental period, the fasting blood glucose levels in the fructose-drinking group were significantly higher than those of the control group, but without hyperglycaemia $(\mathrm{p}<0.05)$ (Fig. 1).

There was no significant difference between the plasma insulin levels of the two groups and the calculated HOMA-IR, even though there was a tendency for elevation $(p>0.05)$ (Fig. 2). 


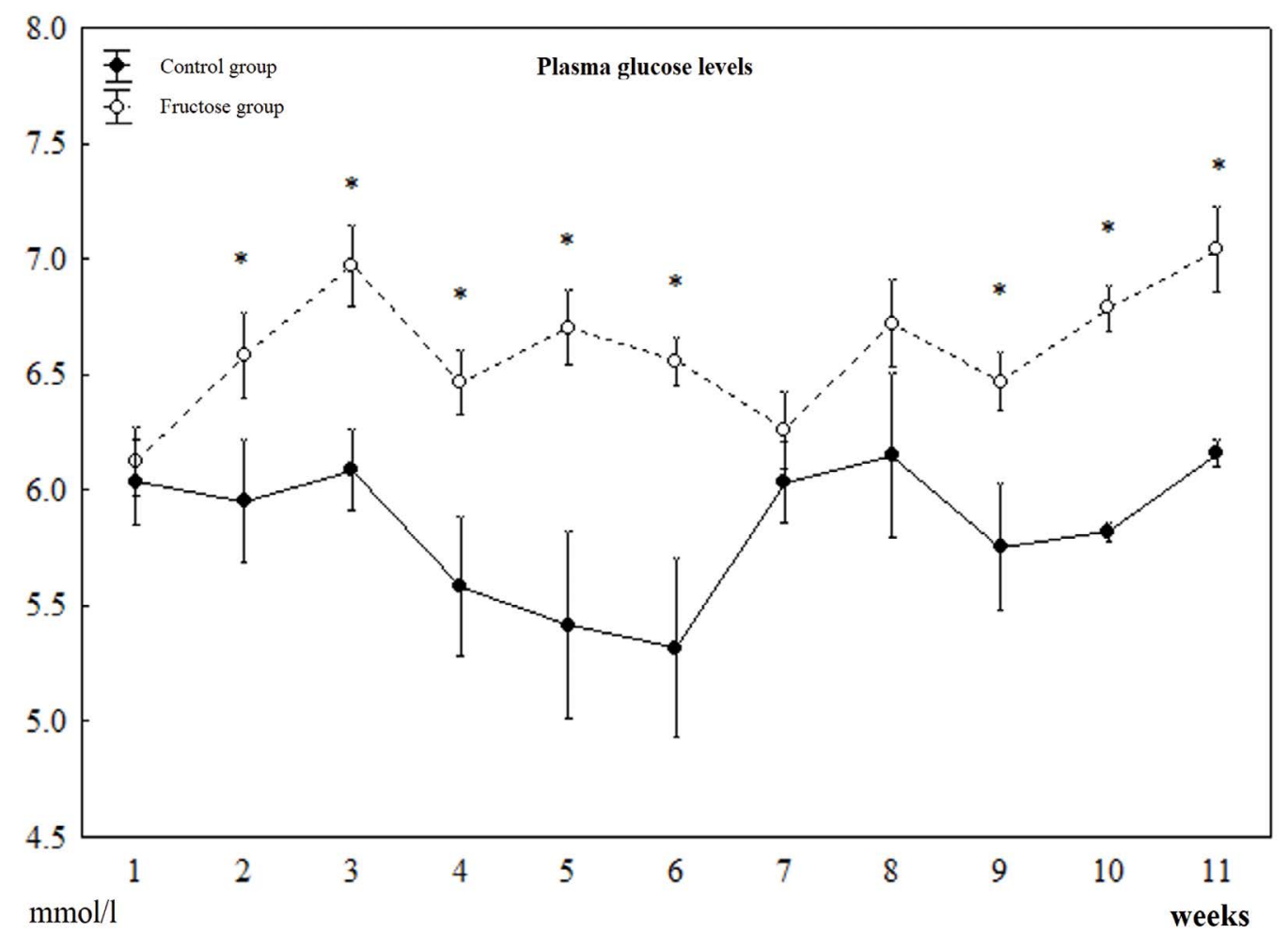

Figure 1. Fasting blood glucose levels monitoring weekly during the experimental period.

${ }^{*}$ vs. controls, $\mathrm{p}<0.05$

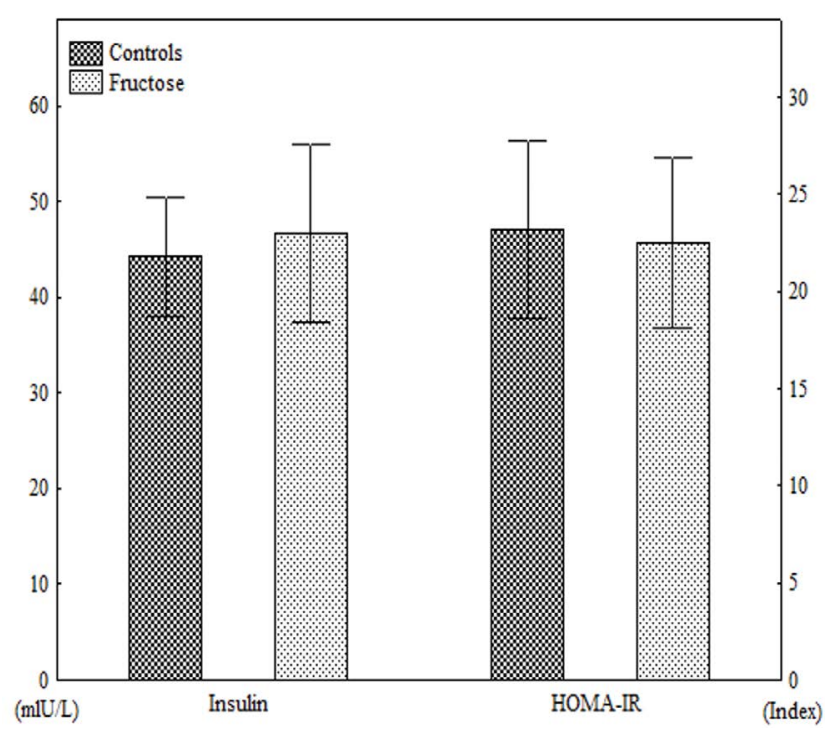

Figure 2. Plasma insulin concentration and HOMA-IR at the end of the experiment.

\section{Lipid profile and creatinine levels}

There were significant differences between the plasma lipids of the two groups, with the exception of the total cholesterol. The fructose drinking induced a significant increase in TG, with concentration twice as high as that of the control group. Creatinine concentrations were significantly higher in the fructose-drinking group $(p<0.05)$ (Table 1).

Table 1. Lipid profile and plasma creatinine levels at the end of experiment

\begin{tabular}{lll}
\hline Parameter & Control group & $\begin{array}{l}\text { Fructose-drinking } \\
\text { group }\end{array}$ \\
\hline CHOL $(\mathrm{mmol} / \mathrm{l})$ & $1.33 \pm 0.04$ & $1.24 \pm 0.08$ \\
LDL $(\mathrm{mmol} / \mathrm{l})$ & $0.43 \pm 0.04$ & $0.28 \pm 0.05^{\star}$ \\
HDL $(\mathrm{mmol} / \mathrm{l})$ & $0.54 \pm 0.02$ & $0.43 \pm 0.04^{\star}$ \\
TG $(\mathrm{mmol} / \mathrm{l})$ & $0.81 \pm 0.06$ & $1.73 \pm 0.36^{\star}$ \\
Creatinine $(\mu \mathrm{mol} / \mathrm{l})$ & $51.22 \pm 1.85$ & $66.25 \pm 2.20^{\star}$ \\
\hline
\end{tabular}

${ }^{*}$ vs. controls, $p<0.05$, TG: triglycerides; CHOL: total cholesterol; HDL: high-density lipoprotein cholesterol; LDL: low-density lipoprotein cholesterol.

All calculated lipid indexes (Table 2) were higher in the fructose-drinking group, showing a statistically significant difference with the indexes of the control group $(p<0.05)$, with the exception of LCI which displayed only a tendency for an increase. 
Table 2. Lipid indexes at the end of experiment

\begin{tabular}{lll}
\hline Parameter & Control group & $\begin{array}{l}\text { Fructose-drinking } \\
\text { group }\end{array}$ \\
\hline $\begin{array}{l}\text { Total cholesterol/ } \\
\text { HDL ratio }\end{array}$ & $2.51 \pm 0.08$ & $2.92 \pm 0.14^{*}$ \\
$\begin{array}{l}\text { Triglycerides/HDL } \\
\text { ratio }\end{array}$ & $1.54 \pm 0.13$ & $3.74 \pm 0.6^{*}$ \\
LCI & $0.86 \pm 0.25$ & $1.15 \pm 0.6$ \\
AI & $1.70 \pm 0.06$ & $2.18 \pm 0.15^{*}$ \\
\hline
\end{tabular}

${ }^{\star}$ vs. controls, $p<0.05$, HDL: high-density lipoprotein cholesterol; LCI: lipoprotein combine index; AI: atherogenic index

\section{Plasma renin and angiotensin II concentrations}

There were significant differences between the plasma levels of renin of the two groups ( $p>0.05)$ (Fig. 3).

\section{Morphometric analysis}

The morphometric analysis (Table 3) showed no statistically significant differences between the two study groups $(p>0.05)$ and all of the investigated parameters had similar values.
Table 3. Morphometric analysis at the end of experiment

\begin{tabular}{lll}
\hline Parameter & Control group & $\begin{array}{l}\text { Fructose-drinking } \\
\text { group }\end{array}$ \\
\hline BW $(\mathrm{g})$ & $336.67 \pm 12.86$ & $338.89 \pm 15.11$ \\
WC $(\mathrm{mm})$ & $198.89 \pm 3.31$ & $203.89 \pm 3.89$ \\
NAL $(\mathrm{mm})$ & $225.56 \pm 2.56$ & $225.00 \pm 2.04$ \\
Waist-to-stature ratio & $0.88 \pm 0.01$ & $0.91 \pm 0.02$ \\
Lee Index & $308.04 \pm 1.55$ & $309.33 \pm 3.49$ \\
\hline
\end{tabular}

* vs. controls, $p<0.05, \mathrm{BW}$ : body weight; WC: waist circumference; NAL: naso-anal length

\section{Ang II-induced intestinal contractions}

A graphical visualization of the average contractile process of Ang II-induced smooth muscle activity of the intestinal samples ( $n=9$, per each segment, for each group) from both groups is presented in Figs 4-6. The amplitude of the contractions of the ileum from the fructose drinking group was similar to that of the controls (Fig. 4).

There was no significant difference in the AUC $(p>0.05)$ of both groups $\left(232.1 \pm 34.5 \mathrm{~g}^{\star} \mathrm{s}\right.$ controls vs. $271.5 \pm 38.9$ $\mathrm{g}^{\star} \mathrm{s}$ experimental). The investigation of time parameters demonstrated a significantly faster initiation, followed by

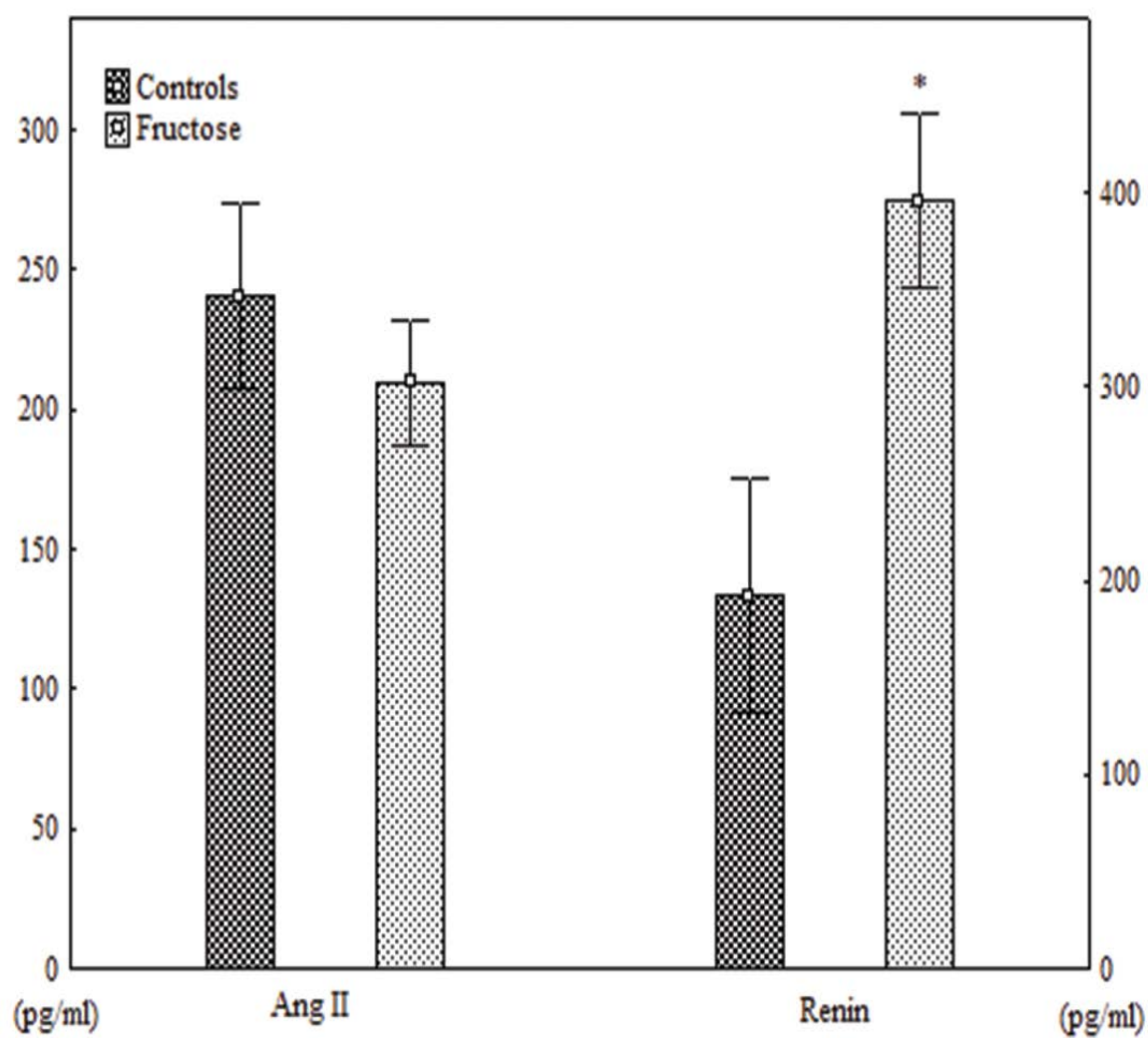

Figure 3. Plasma renin and angiotensin II levels at the end of experiment.

${ }^{*}$ vs. controls, $\mathrm{p}<0.05$ 


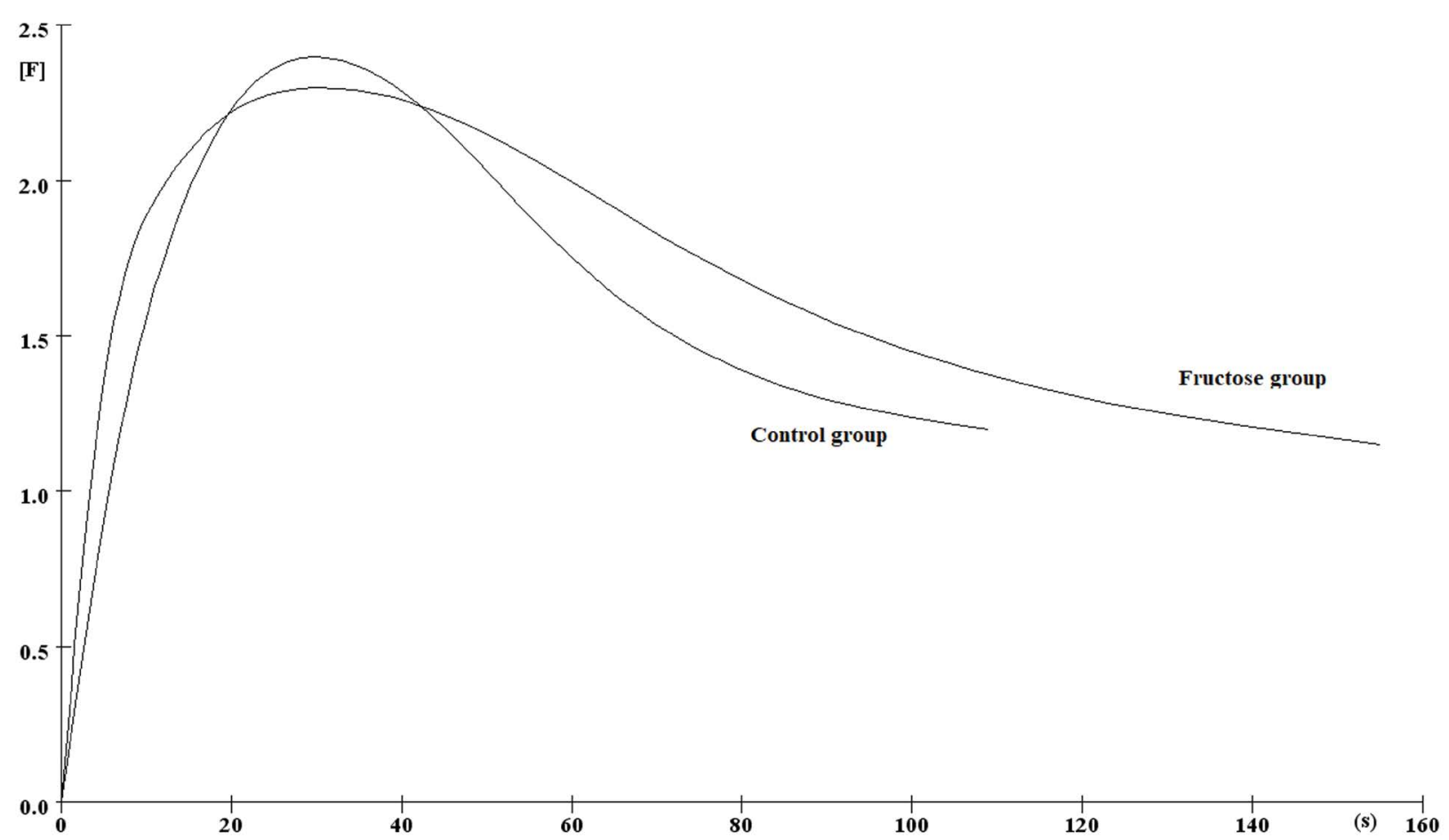

Figure 4. Graphic image of the average contractile pattern of angiotensin II-induced contractions of ileum strips ( $\mathrm{n}=9$ for each group) from control and fructose-drinking group.

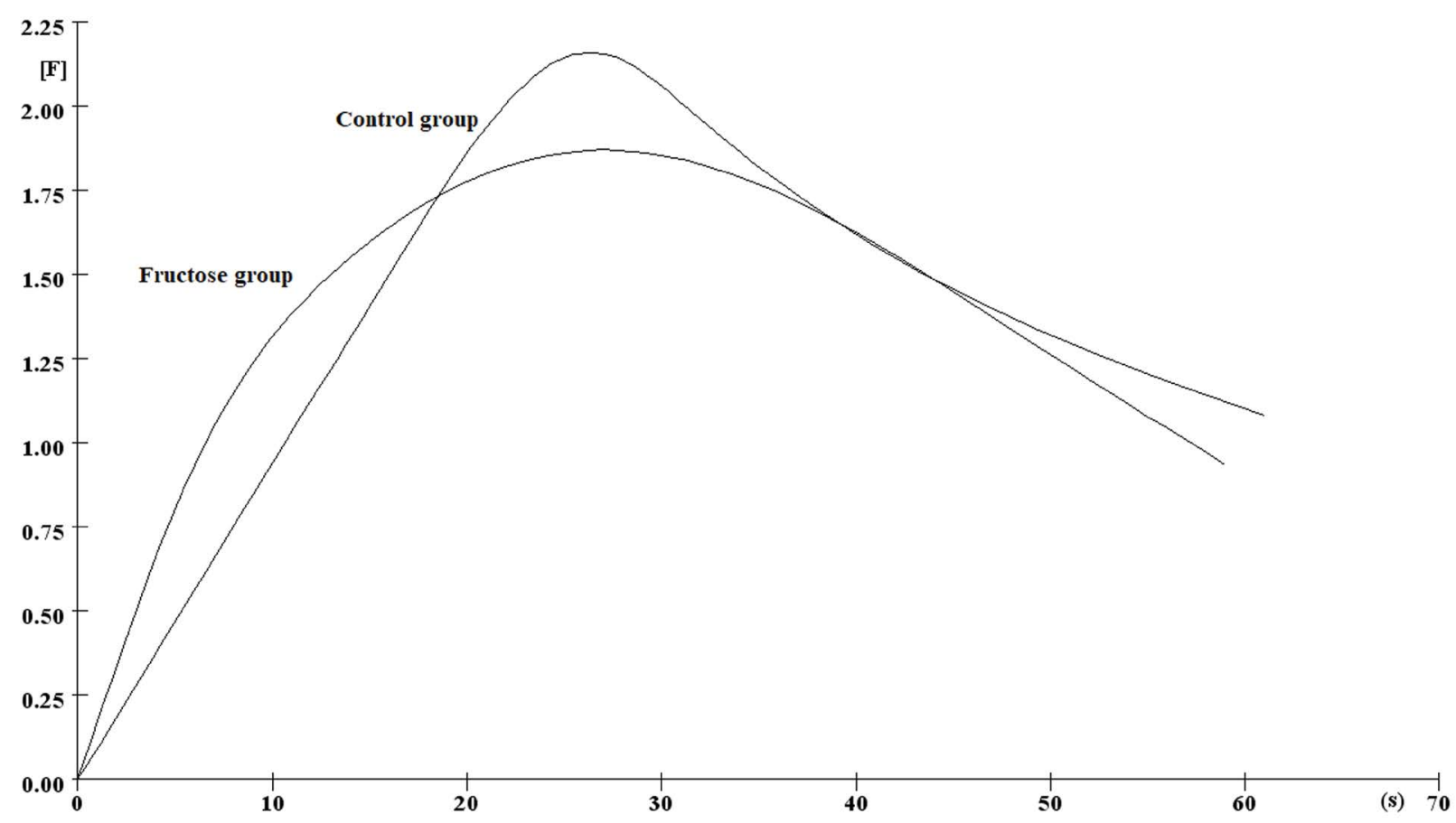

Figure 5. Graphic image of the average contractile pattern of angiotensin II-induced contractions of colon strips ( $\mathrm{n}=9$ for each group) from control and fructose-drinking group.

a prolonged duration of the contraction of the ileum from the fructose-drinking group (Table 4).

The amplitude of the contractions of the colon (Fig. 5) from the fructose-drinking group $(1.87 \pm 0.22 \mathrm{~g})$ was lower, but not statistically significant compared with the con- trol one $(2.16 \pm 0.21 \mathrm{~g}), p>0.05$. There was no significant difference in the AUCs of the two groups as well $(91.8 \pm 19.3$ $\mathrm{g}^{*} \mathrm{~s}$ vs. $\left.83.7 \pm 17.9 \mathrm{~g}^{*} \mathrm{~s}, p>0.05\right)$. The time parameters of colon contractions (Table 4) were similar in both groups, with the exception of Thc of the fructose-drinking group, 


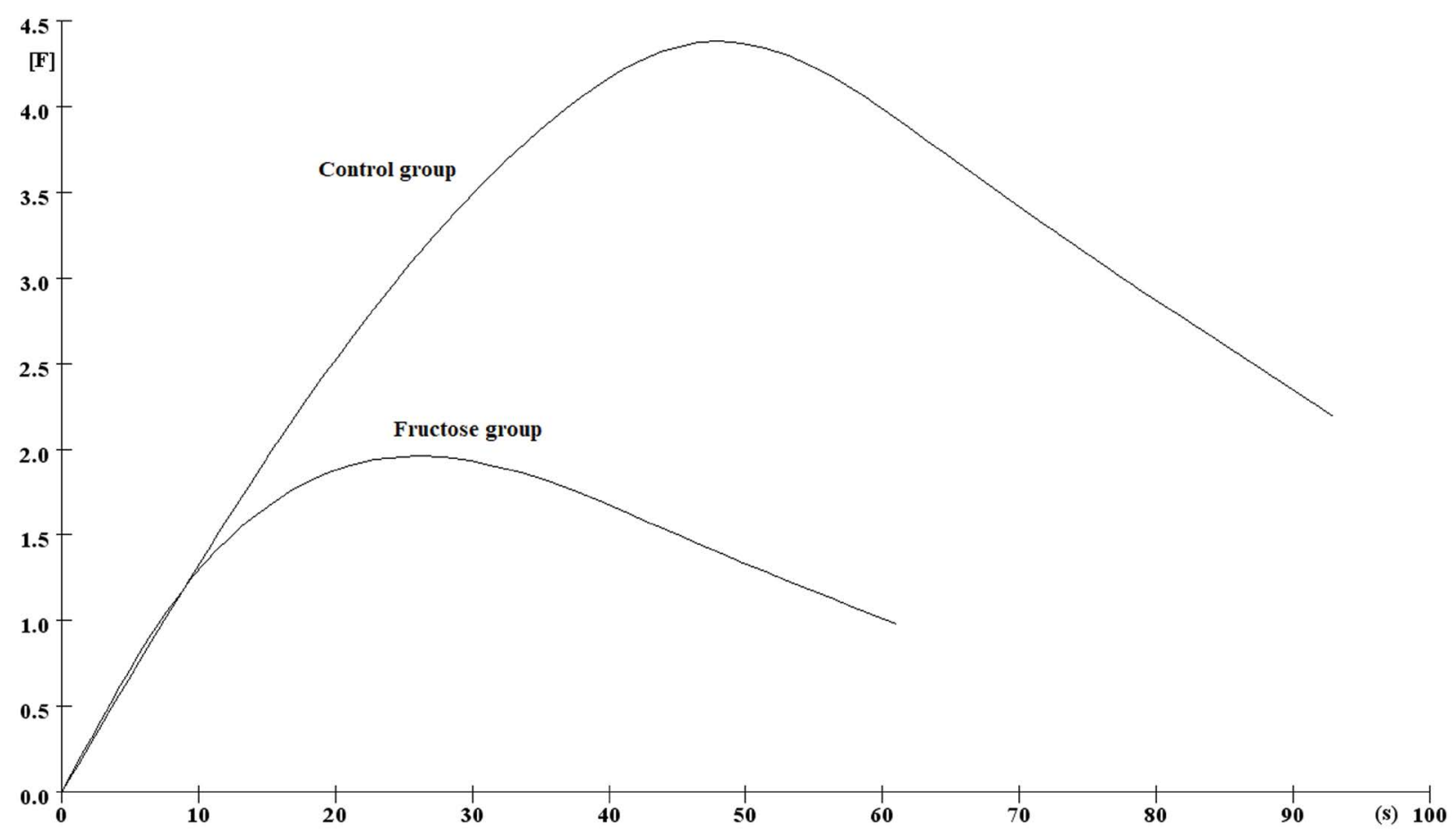

Figure 6. Graphic image of angiotensin II-induced contractions of rectal strips ( $\mathrm{n}=9$ for each group) from control and fructosedrinking group.

Table 4. Time-parameters of angiotensin II -induced smooth muscle contractions

\begin{tabular}{|c|c|c|c|c|}
\hline & The (s) & $\mathrm{Tc}(\mathrm{s})$ & Thr (s) & $\operatorname{Tchr}(\mathbf{s})$ \\
\hline Ileum_C $(\mathrm{n}=9)$ & $7.3 \pm 1.25$ & $30.25 \pm 5.3$ & $78.8 \pm 7.3$ & $109 \pm 8.3$ \\
\hline Ileum_F $(\mathrm{n}=9)$ & $4.3 \pm 0.77^{\star}$ & $29.6 \pm 4.1$ & $126.1 \pm 19.2^{*}$ & $155.7 \pm 27.2^{\star}$ \\
\hline Colon_C $(\mathrm{n}=9)$ & $11.5 \pm 1.5$ & $26.5 \pm 5.5$ & $34.5 \pm 4.8$ & $61 \pm 8.8$ \\
\hline Colon_F $(\mathrm{n}=9)$ & $5.75 \pm 0.48^{\star}$ & $27.25 \pm 3.4$ & $31.8 \pm 5.2$ & $59 \pm 8.2$ \\
\hline Rectum_C $(\mathrm{n}=9)$ & $17 \pm 2.8$ & $45 \pm 6.5$ & $48 \pm 5$ & $93 \pm 11.1$ \\
\hline Rectum_F $(n=9)$ & $7.2 \pm 1.02^{\star}$ & $26 \pm 4^{*}$ & $34.8 \pm 5.9^{*}$ & $60.8 \pm 7.9^{*}$ \\
\hline
\end{tabular}

* vs. controls, $p<0.05$, C: control group; F: fructose-drinking group; Thc: half-contraction time; Tc: contraction time; Thr: half-relaxation time; Tchr: contraction plus half-relaxation time.

demonstrating a faster initiation of the contraction.

Regarding rectum, both the amplitude and AUC of the contractions from the fructose-drinking group were significantly lower $(p<0.05)$ when compared with those of the controls $\left(1.96 \pm 0.13 \mathrm{~g}\right.$ vs. $4.38 \pm 0.56 \mathrm{~g}$ and $73.5 \pm 10.9 \mathrm{~g} \mathrm{~g}^{\star} \mathrm{v}$. $274 \pm 22.7 g^{\star}$ s, respectively) (Fig. 6). There was a significant difference between all of the time-parameters of the two groups $(p<0.05)$ (Table 4$)$, indicating both faster initiation and completion of the rectal contraction from the fructose-drinking animals.

\section{DISCUSSION}

The present study aimed at developing fructose-induced metabolic disorders in rats and the investigation of their impact on Ang II-induced smooth muscle intestinal motility.
Generally, the metabolic perturbations in fructose-drinking rodents are divergent depending on the used rats, the concentration of the fructose solution and the duration of the experiment. ${ }^{15}$ The results of our experiment showed that drinking of $15 \%$ fructose solution for 11 weeks in addition to a single treatment with low dose streptozotocin induced moderate metabolic perturbations, mainly in the lipid profile of the rats. These results are consistent with the findings of other researchers, about the elevated serum lipids as a consequence of the fructose in food diet ${ }^{1,5,6}$ or in drinking water. ${ }^{16,27}$ The lipid indexes, which were currently considered as more significant markers for increased metabolic risk ${ }^{20}$, were especially indicative. In our experiment, however, the rats in fructose group did not become obese as we did not observe any differences in BW, WC and the other morphometric parameters between the two groups. Our results are consistent with the findings of many au- 
thors ${ }^{1,18,28,29}$ who reported that the fructose diet did not induce an increase in body weight of the rats. The impact of fructose on weight and fat gain is still debatable. ${ }^{29}$ Probably, to induce such weight gain, it was necessary to use a higher amount of fructose alone or in combination with high fats/ glucose diet and to increase the experiment duration.

The mild changes in fasting glucose levels in fructose-drinking group did not affect significantly the plasma insulin levels and HOMA-IR indexes, suggesting the lack of insulin resistance. Similar findings have been reported by other authors. ${ }^{18,29}$ There is evidence that even the low fructose consumption affects the pancreatic islets without altering the serum insulin concentrations. ${ }^{29}$

The significant increase of plasma creatinine concentration in the fructose-drinking group indicated a starting damage of the kidney functions. Similar results were described by Gersch et al. ${ }^{30}$ who reported an acceleration of chronic kidney disease in rats on high fructose diet. The higher plasma renin levels after 11-week period of drinking fructose is in agreement with the hypothesis of the hyperactivity of RAS in both diabetes and MetS. ${ }^{1,11}$ It was further supported in the current study by the measured alterations of intestinal response to Ang II. This reveals a possible impact of fructose and the fructose drinking-induced metabolic perturbations on the smooth muscle properties. The three types of tested intestinal segments - ileum, colon and rectum, did not show an equal change in their response to Ang II when compared to the controls. From our results, we could conclude that the changes in the activity of ileum are still at an early stage of development as the only significant difference between the two groups is in the duration of their contraction. Regarding the large intestine, a significant worsening of the parameters of Ang II-induced contraction could be noted. Obviously the metabolic disorders gradually alter the intestinal motility in the distal direction of the gut with rectum being the most seriously affected organ. Our findings are consistent with Touw et al. ${ }^{31}$, who had reported a diminished motor activity of the large intestine in diabetic mice.

The role of oxidative stress in the pathogenesis of diabetes and in the development of consequent gastrointestinal complications is well recognized. ${ }^{9,32}$ The increased formation of ROS causes loss of enteral neurons, which in turn could lead to gastrointestinal dysfunction. ${ }^{10}$ It is the most likely cause for the reduced response to Ang II stimulation in the large intestine segments in the fructose-drinking group. The findings of a previous study of our research group ${ }^{33}$ are in support of this hypothesis: we found elevated levels of ROS and other markers of oxidative stress in tissue homogenates from diabetic rats. Furthermore, it was found that the large intestine is more sensitive to the oxidative stress caused by diabetes when compared to the small intestine. ${ }^{34}$ Another likely explanation for the reduced rectal contractile activity might be the accumulation of AGE products in the smooth muscle cells as a result of the increased fructose consumption. ${ }^{2}$ The upregulated AGE products expression and the proliferation of the muscle layer in different gastrointestinal segments of diabetic rats ${ }^{7,35}$ add support to this hypothesis. The accumulation of AGE products might be a factor for the structure remodeling and the change in the contractile properties of the intestinal smooth muscle.

\section{CONCLUSIONS}

Drinking $15 \%$ fructose solution for 11 weeks combined with a single $20 \mathrm{mg} / \mathrm{kg}$ streptozotocin injection induced moderate metabolic changes such as elevation of creatinine levels accompanied by dyslipidaemia and elevated renin levels. The fructose drinking and the subsequently developed metabolic disorders modified the Ang II-induced intestinal activity causing a gradual alteration in the distal direction, with the rectum being the most strongly affected organ. Further studies are needed in order to reveal the exact mechanism of the fructose diet on the RAS and Ang II-induced intestinal motility.

\section{Acknowledgements}

This study was supported by Grant 9/2016 from Trakia University, Stara Zagora, Bulgaria and the National Scientific Program "Young Scientists and Postdoctorants", Trakia University - Bulgaria.

\section{Competing interests}

The authors have declared that no competing interests exist.

\section{REFERENCES}

1. Rabie EM, Heeba GH, Abouzied MM, et al. Comparative effects of aliskiren and telmisartan in high fructose diet-induced metabolic syndrome in rats. Eur J Pharmacol 2015; 760:145-53.

2. Gugliucci A. Formation of fructose-mediated advanced glycation end products and their roles in metabolic and inflammatory diseases. Adv Nutr 2017; 8(1):54-62.

3. Grundy SM. Pre-diabetes, metabolic syndrome, and cardiovascular risk. J Am Coll Cardiol 2012; 59(7):635-43.

4. Swarup S, Zeltser R. Metabolic syndrome. In: StatPearls [Internet]. Treasure Island (FL): StatPearls Publishing; 2019. Available from: https://www.ncbi.nlm.nih.gov/books/NBK459248/

5. Lozano I, Van der Werf R, Bietiger W, et al. High-fructose and highfat diet-induced disorders in rats: impact on diabetes risk, hepatic and vascular complications. Nutr Metab (Lond) 2016; 13:15.

6. Chou CL, Lin H, Chen JS, et al. Renin inhibition improves metabolic syndrome, and reduces angiotensin II levels and oxidative stress in visceral fat tissues in fructose-fed rats. PLoS One 2017; 12(7):e0180712.

7. Zhao J, Chen P, Gregersen H. Morpho-mechanical intestinal remodeling in type 2 diabetic GK rats - is it related to advanced glycation end product formation? J Biomech 2013; 46(6):1128-34. 
8. Kim SJ, Park JH, Song DK, et al. Alterations of colonic contractility in long-term diabetic rat model. J Neurogastroenterol Motil 2011; 17(4):372-80.

9. Kashyap P, Farrugia G. Oxidative stress: key player in gastrointestinal complications of diabetes. Neurogastroenterol Motil 2011; 23(2): 111-4.

10. Chang MJ, Xiao JH, Wang Y, et al. 2, 3, 5, 4'-tetrahydroxystilbene2-O-beta-D-glucoside improves gastrointestinal motility disorders in STZ - induced diabetic mice. PLoS One 2012; 7(12):e50291.

11. Tran LT, Yuen VG, McNeill JH. The fructose-fed rat: a review on the mechanisms of fructose-induced insulin resistance and hypertension. Mol Cell Biochem 2009; 332(1-2):145-59.

12. Andreozzi F, Laratta E, Sciacqua A, et al. Angiotensin II impairs the insulin signalling pathway promoting production of nitric oxide by inducing phosphorylation of insulin receptor substrate-1 on Ser312 and Ser616 in human umbilical vein endothelial cells. Circ Res 2004; 94(9):1211-8.

13. Yang X, Zhao H, Sui Y, et al. Additive interaction between the reninangiotensin system and lipid metabolism for cancer in type 2 diabetes. Diabetes 2009; 58(7):1518-25.

14. Leung E, Rapp JM, Walsh LK, et al. Characterization of angiotensin II receptors in smooth muscle preparations of the guinea pig in vitro. J Pharmacol Exp Ther 1993; 267(3):1521-8.

15. Sadeghi A, Beigy M, Alizadeh S, et al. Synergistic effects of ad-libitum low-dose fructose drinking and low-dose streptozotocin treatment in Wistar rats: a mild model of type 2 diabetes. Acta Med Iran 2017; 55(5):304-10.

16. Wilson RD, Islam MS. Fructose-fed streptozotocin-injected rat: an alternative model for type 2 diabetes. Pharmacol Rep 2012; 64(1) 129-39.

17. Georgiev T, Erdogan H, Tolekova A, et al. Angiotensin II receptor blockade - importance for intestinal smooth muscle tone. C R Acad Bulg Sci 2015: 68(3):391-401.

18. Moreno-Fernández S, Garcés-Rimón M, Vera G, et al. High fat/high glucose diet induces metabolic syndrome in an experimental rat model. Nutrients 2018; 10(10):pii: E1502.

19. Ivanova Z, Bjørndal B, Grigorova N, et al. Effect of fish and krill oil supplementation on glucose tolerance in rabbits with experimentally induced obesity. Eur J Nutr 2015; 54(7):1055-67.

20. Cai G, Shi G, Xue S, et al. The atherogenic index of plasma is a strong and independent predictor for coronary artery disease in the Chinese Han population. Medicine 2017; 96 (37):E:8058.

21. Li H, Matheny M, Nicolson M, et al. Leptin gene expression increases with age independent of increasing adiposity in rats. Diabetes 1997; 46(12):2035-9.

22. Egbuonu ACC, Ezeanyika LUS. Effect of L-arginine on markers of metabolic syndrome related to abdominal obesity and disorder of lipid metabolism in female Wistar albino rats. American Journal of Biochemistry 2012; 2(2):7-13.

23. Yankov K. Software utilities for investigation of regulating systems. In: 9th Nat. Conf. "Modern Tendencies in the Development of Fundamental and Applied Sciences". Stara Zagora (Bulgaria), June 1998. Trakia University Publ. House, 401-8.

24. Yankov K. Preprocessing of experimental data in Korelia software. $\operatorname{Tr}$ J Sci 2010; 8 (3):41-8.

25. Raikova R, Aladjov H. Simulation of the motor units control during a fast elbow flexion in the sagittal plane. J Electromyogr Kinesiol 2004; 14(2):227-38.

26. Yankov K. Evaluation of characteristic parameters of dynamic models. In: Romansky R, editor. InfoTech-2011. International Conference on Information Technologies. Sts Constantine and Elena resort, Varna (Bulgaria), September 2011. Technical University of Sofia, 225-34.

27. Frantz EDC, Medeiros RF, Giori IG, et al. Exercise training modulates the hepatic renin-angiotensin system in fructose-fed rats. Exp Physiol 2017; 102(9):1208-20.

28. Aguilera-Mendez A, Hernández-Equihua MG, Rueda-Rocha AC, et al. Protective effect of supplementation with biotin against high-fructose-induced metabolic syndrome in rats. Nutr Res 2018; 57:86-96.

29. Miranda CA, Schönholzer TE, Klöppel E, et al. Repercussions of low fructose-drinking water in male rats. An Acad Bras Cienc 2019; 91(1):e20170705.

30. Gersch MS, Mu W, Cirillo P, et al. Fructose, but not dextrose, accelerates the progression of chronic kidney disease. Am J Physiol Renal Physiol 2007; 293(4):1256-61.

31. Touw K, Chakraborty S, Zhang W, et al. Altered calcium signaling in colonic smooth muscle of type 1 diabetic mice. Am J Physiol Gastrointest Liver Physiol 2012; 302(1):66-76.

32. Gadjeva V, Goycheva P, Nikolova G, et al. Influence of glycemic control on some real-time biomarkers of free radical formation in type 2 diabetic patients: An EPR study. Adv Clin Exp Med 2017; 26(8):1237-43.

33. Georgiev T, Hadzhibozheva P, Georgieva E, et al. Effect of N-[N'-(2chloroethyl)-N'-nitrosocarbamoyl-glycine amide of 2,2,6,6-tetramethyl-4-aminopiperidine-1-oxyl(SLCNUgly) on angiotensin II-mediated smooth muscle activity of organs in pelvic cavity. Bulg Chem Comm 2017; 49:191-8.

34. Jancsó Z, Bódi N, Borsos B, et al. Gut region-specific accumulation of reactive oxygen species leads to regionally distinct activation of antioxidant and apoptotic marker molecules in rats with STZ-induced diabetes. Int J Biochem Cell Biol 2015; 62:125-31.

35. Chen PM, Gregersen H, Zhao JB. Advanced glycation end-product expression is upregulated in the gastrointestinal tract of type 2 diabetic rats. World J Diabetes 2015; 6(4):662-72. 


\title{
Нарушения обмена веществ, вызванные питьевой водой с фрруктозой, влияют на опосредованную ангиотензином II сократимость кишечника у самцов крыс линии Wistar
}

\author{
Цветелин К. Георгиев ${ }^{1}$, Ана Н. Толекова ${ }^{1}$, Николай В. Генов $^{2}$, Лилия Ж. Пашова-Стоянова ${ }^{1}$, \\ Живка И. Цокева ${ }^{1}$, Красимира Г. Нанчева $^{3}$, Росица В. Сандева ${ }^{1}$, Галина С. Илиева ${ }^{1}$, \\ Мария Г. Ганева ${ }^{1}$, Петя В. Хаджибожева ${ }^{1}$ \\ ${ }^{1}$ Кафедра физиологии, патофизиологии и фармакологии, Медицинский факультет, Фракийский университет, Стара Загора, Болгария \\ ${ }^{2}$ Студент медицинского факультета, Фракийский университет, Стара Загора, Болгария \\ ${ }^{3}$ Отделение внутренних болезней и клиническая лаборатория, УМБАЛ „Проф. Д-р Стоян Киркович“, Стара Загора, Болгария
}

Адрес для корреспонденции: Петя Хаджибожева, Кафедра физиологии, патофизиологии и фармакологии, Медицинский факультет, Фракийский университет, Стара Загора, Болгария; E-mail: petia_hadjibojeva@abv.bg; Тел.: +359 886919744

Дата получения: 23 января 2020 Дата приемки: 27 апреля $2020 \bullet$ Дата публикации: 31 декабря 2020

Образец цитирования: Georgiev TK, Tolekova AN, Genov NV, Pashova-Stoyanova LZ, Tsokeva ZI, Nancheva KG, Sandeva RV, Ilieva GS, Ganeva MG, Hadzhibozheva PV. Metabolic disorders induced by fructose-drinking water affect angiotensin II-mediated intestinal contractility in male Wistar rats. Folia Med (Plovdiv) 2020;62(4):802-11. doi: 10.3897/folmed.62.e50410.

\section{Резюме}

Введение: Однозначно установлено, что диета с высоким содержанием фруктозы у крыс вызывает метаболические расстройства, такие как нарушение уровня глюкозы натощак, инсулинорезистентность, дислипидемия и нарушение регуляции ренин-ангиотензиновой системы. Это может привести к дополнительным осложнениям, таким как дисфункция гладких мышц.

Цель: Настоящее исследование направлено на провоцирование метаболических нарушений, вызванных фруктозой, у крыс и изучение их влияния на перистальтику гладких мышц кишечника, индуцированную ангиотензином-II.

Материалы и методы: Взрослых крыс линии Wistar случайным образом разделили на две группы (по 9 крыс в группе): контрольную группу (принимающие питьевую воду) и группу, получавшую фруктозу (15\% фруктозы, растворенной в питьевой воде). В конце экспериментального периода (11 недель) оценивали уровни инсулина, ренина, ангиотензина-II и креатинина в плазме, а также липидный профиль. Также были выполнены морфометрический анализ и расчёт липидного индекса. Сократительные характеристики подвздошной, ободочной и прямой кишки исследовали с помощью стимуляции ангиотензином-ІІ в ванне с изолированными тканями.

Результаты: Наш эксперимент показал, что употребление 15\% раствора фруктозы вызывало диспепидемию, сопровождающуюся повышенными липидными индексами, а также повышением уровня креатинина и ренина в плазме у крыс.

Заключение: Потребление фруктозы и последующее развитие метаболических нарушений изменяют индуцированную Анг - II деятельность кишечника, вызывая постепенное изменение дистального направления, и прямая кишка является наиболее поражённым органом.

\section{Ключевые слова}

ангиотензин II, фруктоза, кишечная дисфункция, метаболические нарушения 